\title{
ANALISIS PERANCANGAN SKATEBOARD \\ DENGAN QUALITY FUNCTION DEPLOYMENT - HOUSE OF QUALITY
}

\author{
Dedeh Kurniasih \\ Jurusan Teknik Industri \\ Fakultas Teknik - Universitas Pasundasn \\ nazlaigra@yahoo.co.id
}

\begin{abstract}
ABSTRAK
Makalah ini membahas penentuan Customer Requirement, Design Requirement dalam House of Quality yang dilakukan pada perancangan produk skateboard. Skateboard merupakan salah satu olahraga ekstrim di dunia dan dapat digunakan oleh setiap orang dari berbagai kalangan baik dilihat dari segi usia, jenis kelamin, maupun berapa lama mereka menggunakan skateboard. Pada umumnya, pengguna skateboard dapat dikategorikan kedalam dua kelompok. Kelompok pertama yaitu para skaters yang benar- benar mendalami olahraga skateboard, sehingga mereka mengambil jalur profesional dalam olahraga ini. Kelompok yang kedua yaitu para skaters yang menggunakan skateboard sebagai sarana hobi. Oleh karena itu perancangan skateboard menjadi penting agar dapat memenuhi tuntutan konsumen.
\end{abstract}

Kata Kunci : House of Quality, Customer Requirement, Design Requirement

\section{PENDAHULUAN}

Skateboard adalah salah satu keluarga besar dari olahraga ekstrim di dunia. Skateboard pertama kali ditemukan dipertengahan tahun 1950, seiring dengan berkembangnya era surfing di daerah California, Amerika Serikat. Dalam beberapa catatan, permainan ini juga populer digolongkan dalam extreme sport. Alasannya adalah faktor bahaya yang dapat ditimbulkan. Semakin sulit rintangan/ track, maka semakin menantang untuk ditaklukkan. Hal tersebut akan lebih memacu adrenalin para skaters daripada track yang biasa- biasa saja.Olahraga skateboard tentunya tidak lepas dari masalah keselamatan atau safetyfactor. Dalam beberapa kasus, olahraga ini dapat menimbulkan cidera yang cukup parah bagi penggunanya. Dari mulai lecet, lebam, sampai dengan patah tulang. Hal ini tentu harus diperhatikan bagi siapapun yang akan maupun sedang menggunakan produk skateboard. Ada dua hal yang harus diperhatikan dalam olahraga skateboard dalam hubungannya dengan keselamatan.

Yang pertama yaitu desain produk skateboard itu sendiri. Skateboard yang baik adalah skateboard yang nyaman dipakai oleh penggunanya, agar dapat meminimalis kesalahan yang diperbuat sehingga resiko terjadi kecelakaan kecil. Contohnya yaitu terpeleset dari skateboard. Hal tersebut bisa terjadi antara lain karena alas skateboard yang licin, sehingga pemakai tidak dapat mengendalikan skateboard-nya dengan baik. Selain itu, wheels yang bersentuhan dengan deks. Hal ini dapat menyebabkan skateboard yang berhenti secara tiba- tiba, sehingga dapat menyebabkan penggunanya terjatuh. Yang kedua yaitu alat keselamatan yang harus digunakan oleh pemakai skateboard. Terdapat beberapa aksesoris yang bisa digunakan oleh para skaters untuk meminimalis cidera apabila mengalami kecelakaan pada saat menggunakan skateboard, biasanya aksesoris tersebut melekat/ digunakan pada badan pemakainya. Aksesoris tersebut antara lain: helm, deker siku, deker lutut, dll.

Pada umumnya, pengguna skateboard dapat dikategorikan kedalam dua kelompok. Kelompok pertama yaitu para skaters yang benar- benar mendalami olahraga skateboard, sehingga mereka mengambil jalur profesional dalam olahraga ini. Biasanya, skaters yang termasuk kelompok ini sering mengikuti kejuaraan- kejuaraan skateboard yang diselenggarakan baik di tingkat nasional, maupun tingkat yang lebih tinggi 
(misalnya internasional). Kelompok ini tentu saja tidak sembarangan dalam memilih produk skateboard yang mereka gunakan. Skateboard tersebut haruslah berkualitas dan memenuhi standar produk skateboard yang dinilai sangat baik. Kelompok yang kedua yaitu para skaters yang menggunakan skateboard sebagai sarana hobi. Untuk kelompok ini, skateboard yang digunakan pun tidak harus memenuhi kualitas tinggi. Yang penting, skateboard tersebut baik dan nyaman untuk digunakan. Beberapa pengguna skateboard mengatakan bahwa bahan roda yang terlalu keras dan memiliki ukuran yang terlalu besar akan membuat tidak nyamannya pengguna pada saat melakukan trik memutar papan.

Komponen bearing pada skateboard juga memiliki peranan yang penting dalam pergerakan roda. Pemilihan bahan bearing yang baik akan menentukan pergerakan roda yang lebih efektif, mengingat bahan yang banyak digunakan pada saat ini adalah bearing yang terbuat dari besi biasa karena biaya materialnya yang murah dibandingkan bahan lain yang lebih baik dan tentunya dengan biaya material yang lebih tinggi. Selain itu pada bagian deks (papan), dimana bahan pembuatannya ada yang terdiri dari tujuh lapisan kayu maple dan dipres dengan menggunakan adonan lem polyvinyl, aluminium, dan besi dengan kekuatan tekanan sebesar 300 psi. Pada kedua ujung papan tersebut terdapat lengkungan yang memiliki sudut lengkung tertentu, dimana hal tersebut akan sangat mempengaruhi pengguna pada saat melompat di atas papan. Bahkan ada papan skateboard yang hanya memiliki lengkungan hanya pada satu sisi saja. Produk hasil rancangan tidak berubah fungsinya dari produk yang ada sebelumnya, namun diharapkan produk tersebut memiliki nilai lebih dilihat dari segi bahan dan terpenuhinya tuntutan konsumen terhadap produk skateboard.

Tujuan dari penelitian ini adalah menentukan keinginan konsumen terhadap perancangan skateboard dengan mempertimbangkan biaya material. Penelitian ini dilakukan untuk memecahkan masalah bagaimana cara menentukan Design Requirement dengan pendekatan Quality Function Deployment.

\section{MODEL DASAR HOUSE OF QUALITY (HOQ)}

Model yang akan digunakan dalam penelitian ini adalah model QFD (Quality Function Deployment) untuk proses perancangan dan perhitungan biaya material (material costing), dimana pada perhitungan biaya material ini fokus utama adalah untuk mendapatkan total biaya komponen dari perancangan produk yang dilakukan. Quality Function Deployment adalah metodologi terstruktur yang digunakan dalam proses perencanaan dan pengembangan produk, yang dapat memudahkan suatu tim kerja dalam menetapkan spesifikasi kebutuhan dan keinginan konsumen, serta mengevaluasi secara sistematis kapabilitas produk atau jasa dalam memenuhi kebutuhan dan keinginan konsumen (Cohen, 1995).

Fokus utama dari QFD adalah melibatkan konsumen pada proses pengembangan produk sedini mungkin. Filosofi yang mendasarinya adalah bahwa konsumen tidak akan puas dengan suatu produk meskipun suatu produk yang telah dihasilkan dengan sempurna bila mereka memang tidak menginginkan atau membutuhkannya. (Tjiptono, 2001) Penerapan metodologi QFD dalam proses perancangan produk diawali dengan pembentukan matriks perencanaan produk, atau sering disebut sebagai House of Quality (HOQ).

Gambar 1. menunjukan bentuk umum HOQ. Dalam gambar ini digunakan simbol A hingga $\mathrm{F}$ yang menunjukan urutan pengisian bagian- bagian dari matriks perencanaan produk tersebut. 


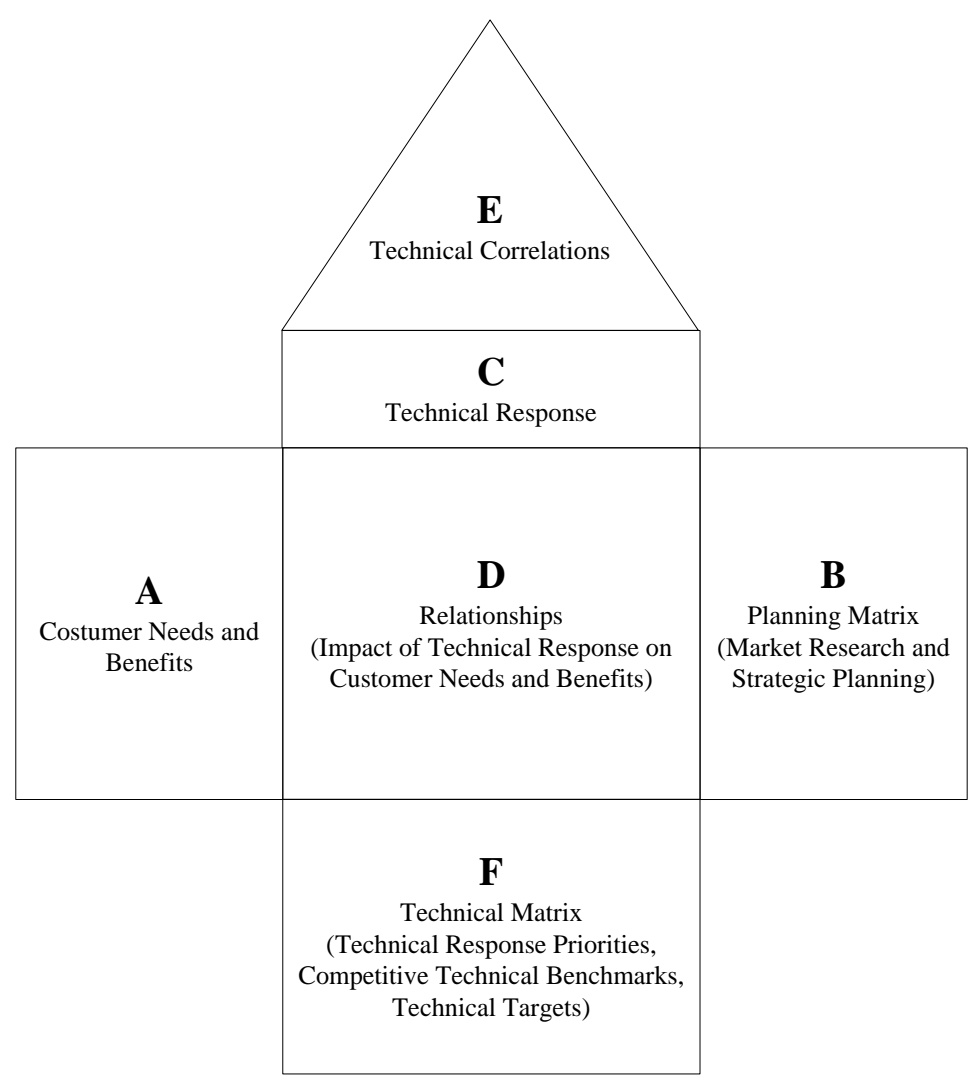

(Sumber : Lou Cohen, 1995, Quality Function Deployment)

GAMBAR 1. House of Quality (HOQ)

\section{Bagian A : Customer Needs and Benefits.}

Bagian pertama dari HOQ adalah Customer Needs and Benefits, atau sering disebut sebagai suara konsumen (Voice of Customer). Bagian ini berisi mengenai kebutuhan dan keinginan konsumen.

\section{Bagian B : Planning Matrix}

Bagian kedua dari HOQ adalah planning matrix. Bagian ini merupakan tempat penentuan sasaran/tujuan produk, didasarkan pada hasil interpretasi tim terhadap data riset pemasaran. Penetapan sasaran merupakan gabungan antara prioritas-prioritas bisnis perusahaan dengan prioritas-prioritas kebutuhan konsumen. Hal ini merupakan tahapan penting dalam perencanaan produk.

\section{Bagian C : Technical Response.}

Bagian ketiga dari HOQ adalah technical response, sering juga disebut Substitute Quality Characteristic (SQCs). Pada bagian ini terjadi proses penerjemahan dari kebutuhan konsumen (voice of customer) ke dalam bahasa pengembang (voice of developer). Proses ini akan mencari jawaban dari pertanyaan how (bagaimana) kebutuhan konsumen dapat dipenuhi. Penerjemahan dilakukan melalui proses brainstorming, yaitu dengan mencari cara-cara yang perlu dilakukan oleh pihak perusahaan untuk memenuhi kebutuhan konsumen. Alat yang biasa digunakan dalam proses ini diantaranya adalah afinity diagram, fish bone diagram, dan tree diagram.

\section{Bagian D : Relationship Matrix.}

Bagian keempat dari HOQ adalah pengisian bagian matrik hubungan (relationships matrix). Dengan menempatkan keinginan konsumen pada badan kiri dan karakteristik teknis pada bagian atas dari HOQ, maka dapat dievaluasi hubungan keduanya secara sistematis. Langkah pertamanya adalah mencari hubungan sebab akibat (impact) yang ditimbulkan o!eh masing-masing karakteristik teknis terhadap kebutuhan konsumen. 


\section{Bagian E : Technical Correlations.}

Bagian kelima dari HOQ adalah technical correlations, matriks yang terletak paling atas dan bentuknya menyerupai atap. Matriks ini digunakan untuk membantu tim dalam menentukan desain yang mengalami bottleneck, dan menentukan kunci komunikasi diantara para desainer. Selain itu, matriks ini juga menggambarkan hubungan dan ketergantungan antar karakteristik teknik yang satu dengan karakteristik teknik yang lainnya. Antar elemen karakterisik teknik tersebut, mungkin saling mempengaruhi, baik positif (saling mendukung) ataupun negatif (saling bertentangan). Dengan melihat direction of improvement dan tiap karakteristik teknis, kemudian didiskusikan dan ditetapkan bersama tim pengembang tingkat hubungan dari setiap karakteristik teknis.

\section{Bagian F : Technical Matrix}

Bagian keenam dari HOQ adalah technical matriks. Bagian ini berisi tiga jenis data, yaitu :

1. Technical Response Priorities.

2. Competitive Technical Benchmarks.

3. Target Technical.

\section{PROSES PERANCANGAN}

Terdapat sejumlah batasan dan asumsi yang digunakan dalam penelitian ini, yaitu sebagai berikut :

1. Produk skateboard yang dirancang memiliki fungsi utama sebagai alat olah raga dan hiburan.

2. Perancangan produk skateboard tidak merubah fungsi produk tersebut.

3. Produk skateboard diperuntukkan bagi remaja \& orang dewasa (usia $14 \mathrm{~s} / \mathrm{d} 30 \mathrm{thn}$.).

4. Segmentasi pengguna produk terdiri dari para pengguna ahli (jalur profesional), dan para pengguna biasa (hobi).

5. Objek penelitian adalah remaja \& orang dewasa (usia $14 \mathrm{~s} / \mathrm{d} 30$ thn.) yang pernah menggunakan skateboard (lebih dari 1 kali)

6. Rancangan produk dibuat bagi orang normal.

7. Tahap perancangan desain produk sampai evaluasi alternatif konsep produk terbaik (dari segi pemilihan material).

Untuk lebih jelas proses perancangan disajikan dalam Gambar 2.

Pengumpulan data melalui observasi dijalankan dengan mengamati dan mencatat pola perilaku orang, obyek, atau kejadian-kejadian melalui cara yang sistematik. Observasi dilakukan dengan mengamati beberapa hal antara lain perilaku fisik, perilaku mengkonsumsi, perubahan mimik atau raut wajah, dan objek (produk kajian). Identifikasi variabel pada penelitian ini dilakukan melalui dua cara, yaitu:

1. Melakukan survei yaitu bertanya kepada para pengguna skateboard mengenai kelebihan dan kekurangan dari produk skateboard yang tersedia saat ini. Dimana, data yang telah didapat tersebut disusun sedemikian rupa sehingga menjadi beberapa variabel dan beberapa item di dalam variabel tersebut yang akan menjadi voice of customer.

2. Konsultasi kepada ahli produk skateboard (misalnya: pengguna yang mahir). Hasil Identifikasi variabel dapat dilihat pada Tabel 1. Pendekatan kuesioner dilakukan pada tahap pengumpulan data , diisi terdiri dari dua bagian, yaitu:

1. Data responden.

Pada bagian ini responden diminta mengisi identitas pribadi secara umum.

2. Desain produk skateboard bagi para pengguna skateboard.

Kuesioner ini terbagi ke dalam dua bagian, yaitu :

a. Preferensi

Pada bagian ini responden diminta menentukan tingkat kepentingan terhadap tiap variabel yang ditanyakan. Data ini berguna untuk menentukan tingkat importance to customer tiap variabel. 
b. Persepsi

Pada bagian ini responden diminta memberikan persepsinya mengenai produk skateboard yang sedang mereka gunakan, juga produk skateboard pesaing. Data ini berfungsi dalam analisis customer satisfaction performance dan competitive satisfaction performance.

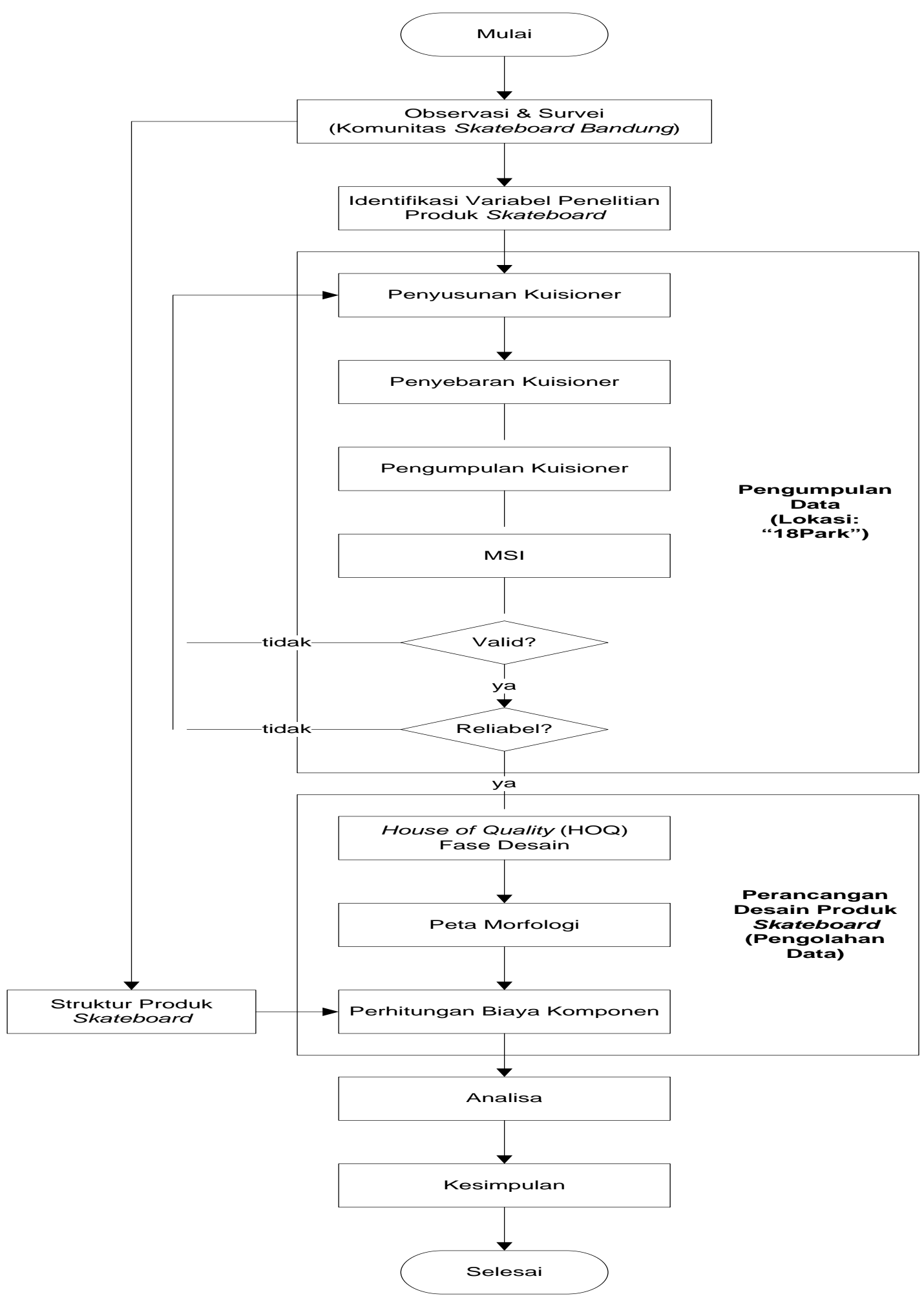

GAMBAR 2. Proses Perancangan 
Uji validitas pada penelitian ini menggunakan rumusan (1), sedangkan uji reliabilitas menggunakan rumusan (2).

$$
\begin{aligned}
& r=\frac{n\left(\sum X Y\right)-\left(\sum X\right)\left(\sum Y\right)}{\sqrt{\left.\left\{n \sum X^{2}-\left(\sum X\right)^{2}\right), n \sum Y^{2}-\left(\sum Y\right)^{2}\right\}}} \\
& \alpha=\frac{k \cdot \bar{r}}{1+(k-1) \bar{r}}
\end{aligned}
$$

Dimana:

$\mathrm{r}$ = koefisien korelasi Pearson antar item dengan variabel bersangkutan

$\mathrm{n}=$ jumlah responden

$\mathrm{X}=$ skor per item

$\alpha=$ koefisien Alfa Cronbach

pertanyaan

$\mathrm{Y}=$ skor total

$\bar{r}=$ koefisien rata-rata korelasi antar variabel

$\mathrm{k}=$ jumlah variabel manifes yang membentuk variabel laten

\begin{tabular}{|c|c|c|}
\hline Item & Sub Variabel & Variabel \\
\hline Deks tahan dari air & \multirow{5}{*}{ Bahan deks kuat } & \multirow{15}{*}{ Tahan lama } \\
\hline Deks tidak mudah keropos & & \\
\hline Deks tidak mudah patah & & \\
\hline Beban maks. deks $\pm 75 \mathrm{~kg}$ & & \\
\hline Umur deks tahan min. \pm 1 tahun & & \\
\hline Truck tidak mudah hancur/ pecah & \multirow{4}{*}{ Truck tidak mudah rusak } & \\
\hline Truck tidak mudah tergores & & \\
\hline Axle Truck tidak mudah patah & & \\
\hline Truck tahan dari air & & \\
\hline Wheels tidak mudah aus/ habis & \multirow{3}{*}{ Wheels tahan lama } & \\
\hline Wheels tahan dari air & & \\
\hline Umur wheels tahan min \pm 6 bulan & & \\
\hline Bearing tahan dari air & \multirow{3}{*}{ Bearing tahan lama } & \\
\hline Bearing tidak mudah aus & & \\
\hline Umur bearing min. \pm 1 tahun & & \\
\hline Tingkat kekasaran Grip tape tinggi & \multirow{3}{*}{ Mudah dikendalikan } & \multirow{6}{*}{ Nyaman digunakan } \\
\hline Tingkat kekerasan wheels sedang & & \\
\hline Ukuran wheels sedang & & \\
\hline Bobot deks ringan & \multirow{3}{*}{ Nyaman digunakan } & \\
\hline Bobot truck ringan & & \\
\hline Jarak deks dengan wheels jauh & & \\
\hline Corak deks tidak mudah hilang & \multirow{4}{*}{ Corak menarik } & \multirow{7}{*}{ Corak dan warna menarik } \\
\hline Corak deks menarik & & \\
\hline Corak wheels menarik & & \\
\hline Corak bearing menarik & & \\
\hline Warna truck tidak mudah pudar & \multirow{3}{*}{ Warna menarik } & \\
\hline Warna truck menarik & & \\
\hline Warna wheels menarik & & \\
\hline
\end{tabular}

TABEL 1. Variabel Penelitian 
Pada tahapan benchmarking, maka ada dua produk sebagai produk pembanding yaitu :

- $\quad$ Produk 1

"Birdhouse Tony Hawk Full Skull”

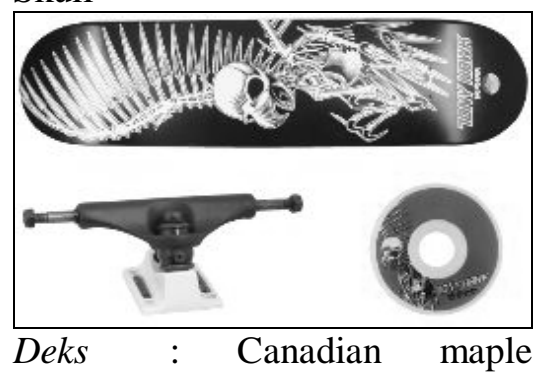

(7,5”x31,25”)

Wheels : Semi Rubber (53mm)

Truck : Alluminum Alloy

Bearing : Stainles steel

Griptape : Yes (Standard)

Risers : No

Harga $\quad$ : Rp 1.295.410
- $\quad$ Produk 2

"Active Stacked Skin Black Complete"

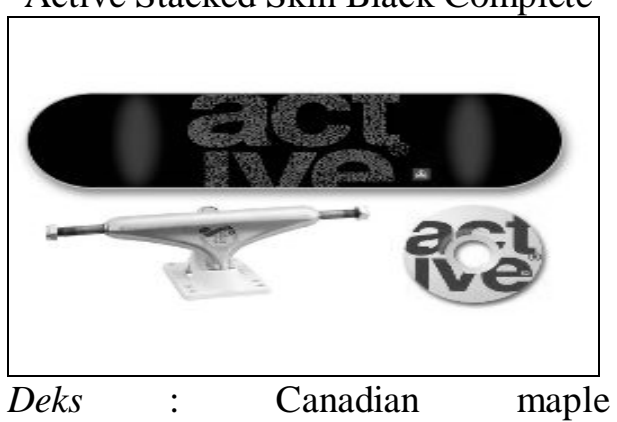

(7,625”x31")

Wheels : Semi Rubber (53mm)

Truck : Besi Cor

Bearing : Stainles steel

Griptape : Yes (Standard)

Risers : No

Harga $\quad:$ Rp 1.114.410,-

Tahap terakhir dari perancangan produk skateboard tersebut adalah evaluasi alternatif dan material costing, dimana nantinya akan dipilih rancangan skateboard yang memiliki kualitas bahan terbaik dan dihitung biaya materialnya. Biaya material ini mencakup seluruh biaya komponen dari rancangan skateboard tersebut. Dengan demikian hasil produk rancangan bisa dikatakan lebih diperuntukan bagi para pengguna skateboard yang ingin memiliki produk skateboard dengan kualitas bahan terbaik, tanpa melihat dari segi harga produk tersebut.

Peta Morfologi dilakukan untuk menentukan alternatif mana yang dipilih dari setiap komponen dilihat dari bahannya, berdasarkan rancangan yang sesuai dengan segmentasi pengguna skateboard tersebut. Terdapat 2 pilihan dalam rancangan skateboard ini, yaitu: rancangan bagi pengguna ahli (jalur profesional) dan rancangan bagi pengguna biasa (hobi). Hasil peta morfologi dapat dilihat pada Tabel 4. Perhitungan biaya material (material costing) dilakukan dengan cara menghitung seluruh biaya komponen terhadap perancangan produk skateboard baik komponen utama maupun komponen tambahannya (hasil selengkapnya disajikan dalam Tabel 5.). Hasil selengkapnya dari HOQ dapat dilihat pada Gambar 3. Terdapat dua jenis komponen dalam produk skateboard ini, yaitu komponen utama dan komponen pendukung. Komponen utama dari produk skateboard adalah: desk, bearing, truck, dan wheels. Sedangkan komponen pendukungnya adalah Set of eight 10-32 bolts (plus nylock nuts). 
TABEL 2. Komponen- komponen Skateboard

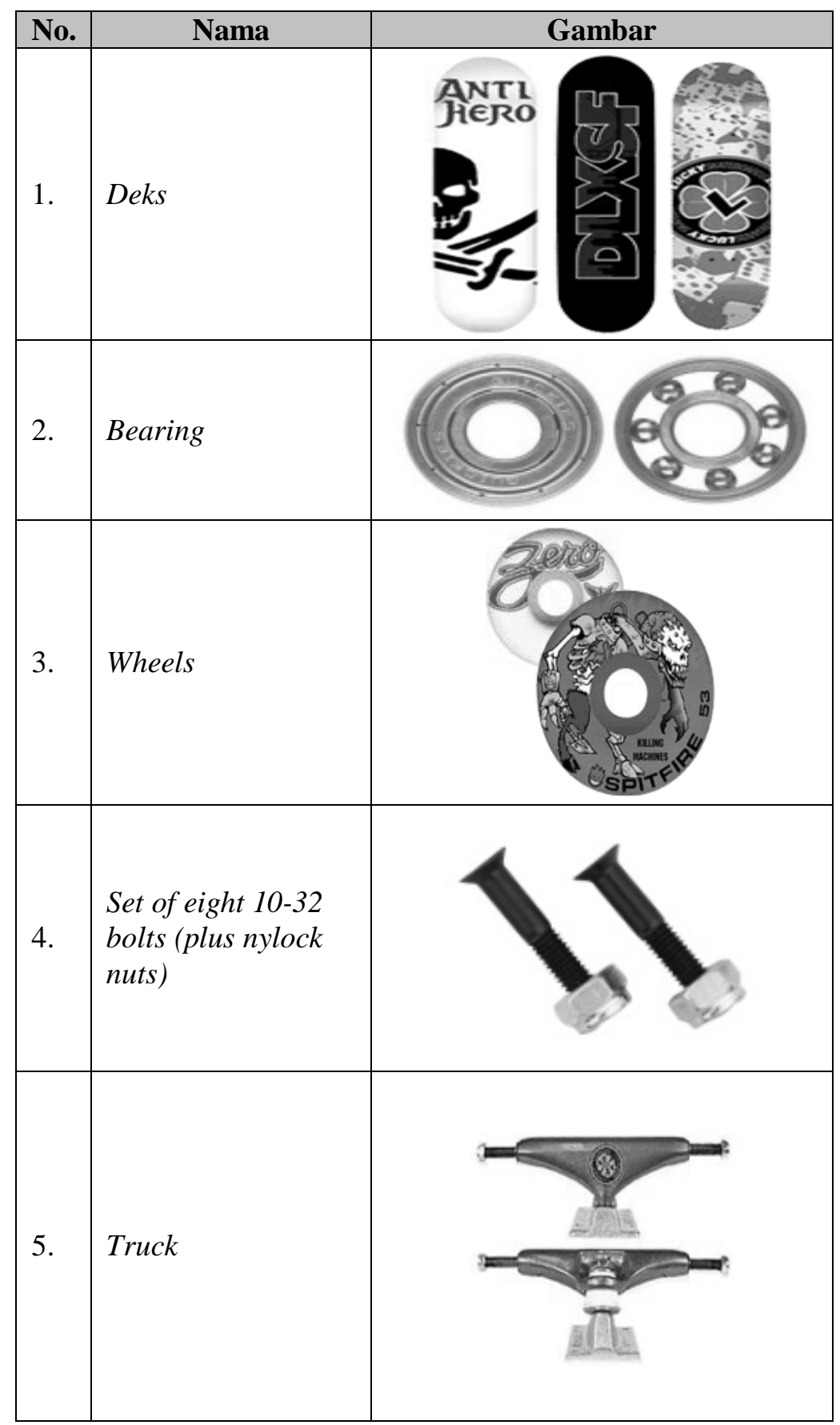


TABEL 3. Komponen- komponen Truck

\begin{tabular}{|c|c|c|}
\hline No. & Nama & Gambar \\
\hline 1. & Axle & \\
\hline 2. & Axle Nut & \\
\hline 3. & Bushing & \\
\hline 4. & Base Plate & \\
\hline 5. & Hanger & \\
\hline 6. & King pin & \\
\hline 7. & King pin Nut & \\
\hline
\end{tabular}




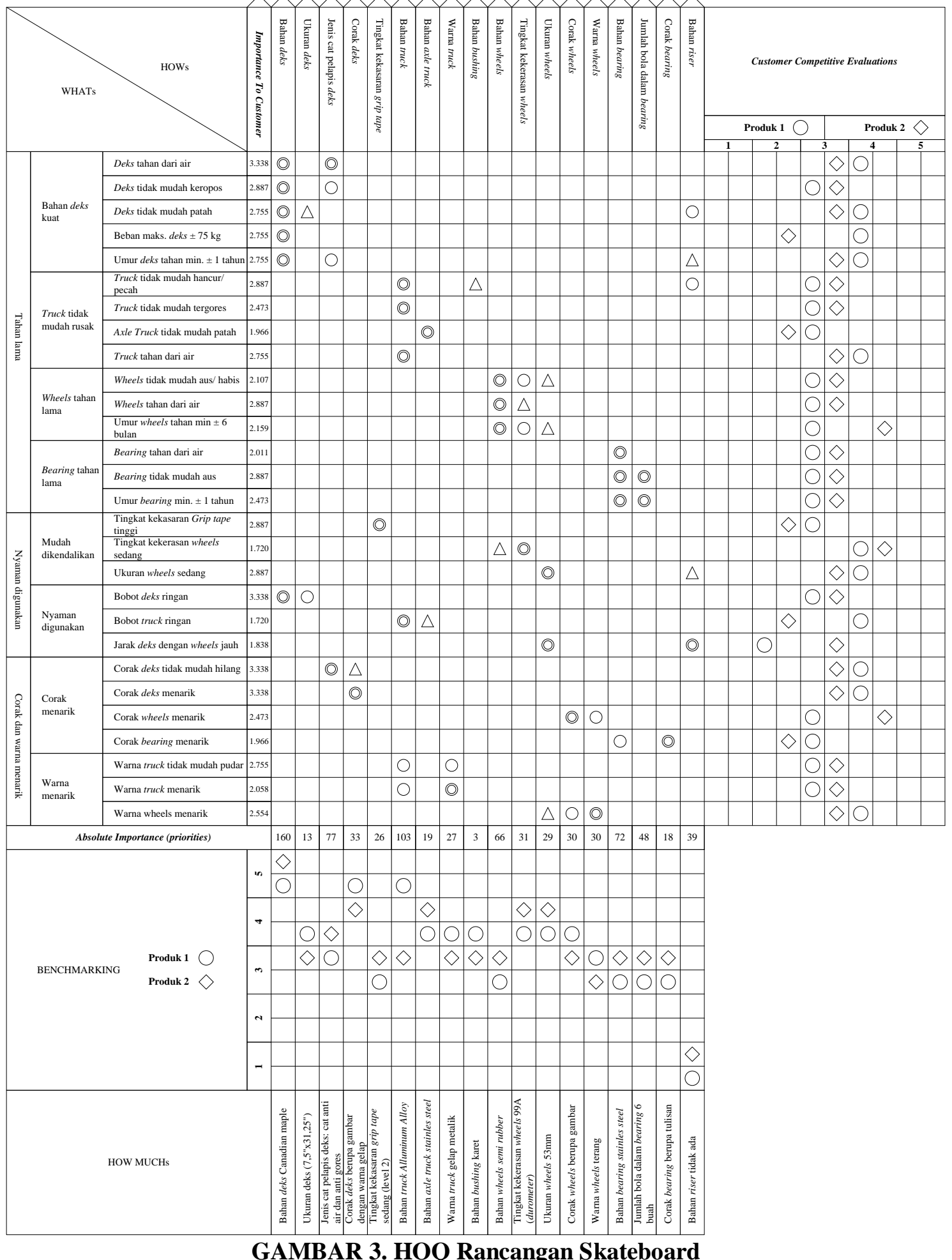


Hasil rancangan akhir dapat dilihat pada Tabel 5, sedangkan untuk perhitungan biaya bahan disajikan pada Tabel 6.

TABEL 4. Peta Morfologi

\begin{tabular}{|c|c|c|c|c|}
\hline \multirow{2}{*}{ No. } & \multirow{2}{*}{ Komponen } & \multicolumn{3}{|c|}{ Alternatif } \\
\hline & & I & II & III \\
\hline 1. & Bahan Bearing & $\begin{array}{l}\text { Stainless steel } \\
\text { Rp 185.000,-- }\end{array}$ & $\begin{array}{l}\text { Ceramic } \\
\text { Rp1.063.500,- }\end{array}$ & $\begin{array}{l}\text { Titanium } \\
\text { Rp 462.500,- }\end{array}$ \\
\hline 2. & Bahan Wheels & $\begin{array}{l}\text { Karet plastik } \\
\text { Rp 268.500,-,- }\end{array}$ & $\begin{array}{l}\text { Plastik } \\
\text { Rp 125.000,- }\end{array}$ & $\begin{array}{l}\text { Polyysethane } \\
\text { BP } 305.500,-\end{array}$ \\
\hline 3. & $\begin{array}{l}\text { Bahan Truck } \\
\text { (Base Plate \& Hanger) }\end{array}$ & $\begin{array}{l}\text { Besi cor } \\
\text { Rp 110.500,-- }\end{array}$ & $\begin{array}{l}\text { Alluminum Alloy } \\
\text { Rp 257.000,- }\end{array}$ & \\
\hline 4. & Bahan Risers & $\begin{array}{l}\text { Plastik } \\
\text { Rp 27.500,- }\end{array}$ & $\begin{array}{l}\text { Karet } \\
\text { Rp 37.000,- }\end{array}$ & \\
\hline
\end{tabular}

TABEL 5. Hasil Akhir Rancangan Produk Skateboard

\begin{tabular}{|c|l|}
\hline No. & \multicolumn{1}{|c|}{ Komponen } \\
\hline 1. & Bahan deks Canadian maple \\
\hline 2. & Ukuran deks (7,5”x31,25”) \\
\hline 3. & Jenis cat pelapis deks: cat anti air dan anti gores \\
\hline 4. & Corak deks berupa gambar dengan warna gelap \\
\hline 5. & Tingkat kekasaran grip tape tinggi (level 3) \\
\hline 6. & Bahan truck Alluminum Alloy \\
\hline 7. & Bahan axle truck stainles steel \\
\hline 8. & Warna truck gelap metalik \\
\hline 9. & Bahan bushing karet \\
\hline 10. & Bahan wheels Polyurethane \\
\hline 11. & Tingkat kekerasan wheels 99A (durometer) \\
\hline 12. & Ukuran wheels 53mm \\
\hline 13. & Corak wheels berupa gambar \\
\hline 14. & Warna wheels terang \\
\hline 15. & Bahan bearing ceramic \\
\hline 16. & Jumlah bola dalam bearing 7 buah \\
\hline 17. & Corak bearing berupa tulisan \\
\hline 18. & Bahan riser karet \\
\hline
\end{tabular}

TABEL 6. Biaya Material Produk Skateboard

\begin{tabular}{|c|l|r|}
\hline No & \multicolumn{1}{|c|}{ Komponen } & $\begin{array}{c}\text { Biaya } \\
\text { (Rp) }\end{array}$ \\
\hline 1. & Deks (canadian Maple 7,5”x31,25”) & $473.500,-$ \\
\hline 2. & Grip Tape (Tingkat kekerasan level 3) & $35.000,-$ \\
\hline 3. & Truck (satu set/ 2 buah) (Alluminum Alloy) & $257.000,-$ \\
\hline 4. & Axle \& Axle Nut (satu set) (Stainless Steel) & $105.000,-$ \\
\hline 5. & King Pin \& King Pin Nut (satu set) (Stainless Steel) & $25.000,-$ \\
\hline 6. & Bushing (satu set) (Karet) & $20.000,-$ \\
\hline 7. & Bearing (satu set/ 8 buah) (Ceramic) & $1.108 .500,-$ \\
\hline 8. & Wheels (satu set/ 4 buah) (Polyurethane) & $305.500,-$ \\
\hline 9. & Risers (satu set/ 2 buah) (Karet) & $37.000,-$ \\
\hline 10. & Set of eight 10-32 bolts (plus nylock nuts) (Stainless Steel) & $37.000,-$ \\
\hline & Total Biaya & $\mathbf{2 . 4 0 3 . 5 0 0 , -}$ \\
\hline
\end{tabular}




\section{ANALISIS PERANCANGAN}

\section{Segmentasi Pengguna Skateboard}

Pada umumnya, pengguna skateboard dapat dikategorikan kedalam dua kelompok. Kelompok pertama yaitu para skaters yang benar- benar mendalami olahraga skateboard, sehingga mereka mengambil jalur profesional dalam olahraga ini. Biasanya, skaters yang termasuk kelompok ini sering mengikuti kejuaraan- kejuaraan skateboard yang diselenggarakan baik di tingkat nasional, maupun tingkat yang lebih tinggi. Kelompok ini tentu saja tidak sembarangan dalam memilih produk skateboard yang mereka gunakan. Skateboard tersebut haruslah berkualitas dan memenuhi standar produk skateboard yang dinilai sangat baik. Kelompok yang kedua yaitu para skaters yang menggunakan skateboard sebagai sarana hobi. Untuk kelompok ini, skateboard yang digunakan pun tidak harus memenuhi kualitas tinggi. Yang penting, skateboard tersebut baik dan nyaman untuk digunakan.

Skateboard dapat digunakan oleh setiap orang dari berbagai kalangan baik dilihat dari segi usia, jenis kelamin, maupun berapa lama mereka menggunakan skateboard. Namun, saat ini mayoritas pengguna skateboard biasanya adalah laki- laki dengan usia rata- rata 15 - 25 tahun. Mereka yang aktif bermainpun rata- rata telah belajar skateboard berkisar antara 1 s.d. 2 tahun lamanya. Selengkapnya dapat dilihat pada Gambar 4 dan 5.

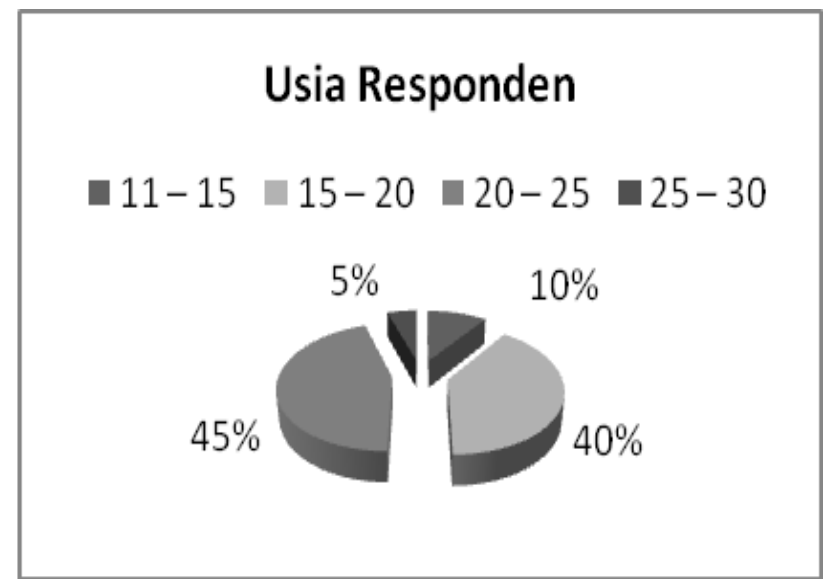

GAMBAR 4. Persentase Usia Responden

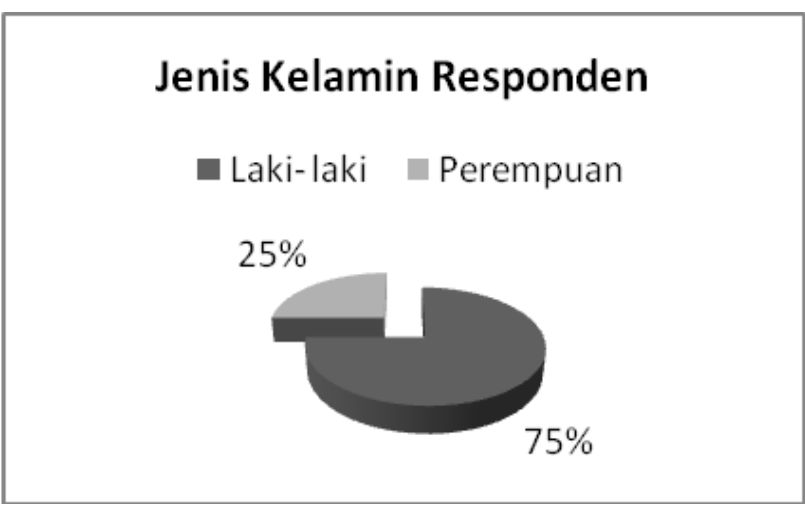

GAMBAR 5. Persentase Jenis Kelamin Responden 


\section{Perancangan Desain Produk Skateboard}

Produk ini merupakan pengembangan dari produk- produk sejenis yang telah beredar sebelumnya. Produk- produk sejenis tersebut dibandingkan dan dievaluasi untuk mengetahui kelebihan dan kekurangannya. Setiap kelebihan dari produk- produk tersebut yang dianggap memenuhi kebutuhan konsumen dimasukkan kedalam spesifikasi produk rancangan, sedangkan kekurangannya dikembangkan untuk mendapatkan spesifikasi yang lebih baik.

Pemilihan bahan dilakukan pada tahap akhir proses perancangan produk skateboard. Tujuannya adalah untuk mendapatkan produk skateboard yang berkualitas dari segi pemilihan bahan. Hal tersebut juga didukung oleh jawaban dari kebutuhan konsumen yang memiliki nilai prioritas paling tinggi pada segi pemilihan bahan. Oleh karena itu, terdapat beberapa alternatif bahan yang dapat digunakan untuk setiap komponen dari skateboard. Alternatif- alternatif tersebut tentunya telah memenuhi kriteria- kriteria yang ada pada setiap komponen. Dilihat dari pemilihan bahan berdasarkan pemilihan bahan kualitas terbaik, rancangan produk skateboard yang ada telah mencakup seluruh segmentasi dari pengguna skateboard yang pada umumnya dapat dikategorikan kedalam dua kelompok. Kelompok pertama yaitu para skaters yang benar- benar mendalami olahraga skateboard, sehingga mereka mengambil jalur profesional dalam olahraga ini. Kelompok yang kedua yaitu para skaters yang menggunakan skateboard sebagai sarana hobi. Untuk kelompok ini, skateboard yang digunakan pun tidak harus memenuhi kualitas tinggi.

Harga seluruh komponen skateboard hasil rancangan mencapai Rp 2.403.500,--. Jumlah tersebut belum termasuk ongkos perakitan untuk menjadi satu unit skateboard yang utuh. Namun, ongkos perakitan dapat diabaikan mengingat proses assembling dari produk itu sendiri tidak cukup sulit. Jumlah harga seluruh komponen skateboard hasil rancangan tersebut cukup besar melihat harga- harga dari produk sejenis yang banyak beredar dipasaran berkisar antara 1 juta s.d. 1,5 juta rupiah per unitnya. Namun dengan jumlah harga tersebut, produk skateboard yang dihasilkan pun akan memiliki kualitas yang tinggi.

Oleh karena itu khusus untuk pengguna skateboard yang termasuk kedalam kelompok kedua, spesifikasi skateboard tidaklah harus mengikuti rancangan terpilih di atas. Karena penggunaannya yang hanya sebagai sarana hobi, pemilihan bahan dari setiap komponen tidaklah harus berkualitas tinggi. Yang perlu diperhatikan, bahan komponen tersebut harus cukup aman untuk digunakan. Misalnya untuk komponen bearing, bahan stainless steel sudah cukup aman untuk digunakan. Karena selain memiliki ketahan yang cukup kuat, bahan ini memiliki ongkos produksi serta ongkos bahan mentah yang tidak terlalu mahal sehingga menghasilkan harga komponen yang relatif terjangkau. Sama halnya dengan komponen wheels dan truck (base plate \& hanger). Pemilihan bahan untuk komponen wheels bisa dipilih bahan karet plastik yang harganya tidak terlalu mahal namun cukup nyaman untuk digunakan. Pemilihan bahan untuk komponen truck (base plate \& hanger) juga bisa dipilih dengan bahan besi cor.

Dengan demikian, spesifikasi produk dalam hal pemilihan bahan sangat tergantung dari tujuan dalam menggunakan produk tersebut. Bila ingin mendapatkan produk yang berkualitas, maka kita dapat memilih produk yang terdiri dari komponenkomponen dengan bahan kualitas tinggi. Namun bila ingin menggunakan produk hanya untuk sarana hobi, dapat memilih produk dengan komponen- komponen yang sederhana, namun layak dan aman untuk digunakan. 


\section{KESIMPULAN}

1. Keinginan konsumen akan produk skateboard yang akan dirancang mencakup hal- hal seperti pemilihan bahan, ukuran, jenis cat pelapis, dan corak komponen deks; tingkat kekasaran griptape; bahan dan warna truck; bahan axle truck; bahan bushing; bahan, tingkat kekerasan, ukuran, corak, dan warna komponen wheels; bahan, jumlah bola, dan corak komponen bearing; serta bahan riser.

2. Rancangan produk skateboard yang sesuai dengan keinginan konsumen meliputi spesifikasi berikut:
Bahan deks Canadian
j. Bahan wheels Polyurethane
b. Ukuran deks (7,5”x31,25”)
k. Tingkat kekerasan wheels 99A (durometer)
c. Jenis cat pelapis deks: cat anti air dan anti gores
l. Ukuran wheels 53mm
d. Corak deks berupa gambar
m. Corak wheels berupa gambar
dengan warna gelap
n. Warna wheels terang
e. tinggi (level 3)
Bahan truck Alluminum
f. Alloy
o. Bahan bearing ceramic
g. Bahan axle truck stainles steel
p. Jumlah bola dalam bearing 7 buah
h. Warna truck gelap metalik
i. Bahan bushing karet
q. Corak bearing berupa tulisan
r. Bahan riser karet

\section{DAFTAR PUSTAKA}

[1] Cohen, Lou, 1995, Quality Function Deployment: How To Make QFD Work for You, Addison-Wesley Publishing Company, United States of America.

[2] Kotler, Philip, 2002, Manajemen Pemasaran, Jilid 1, Prenhallindo, Jakarta.

[3] — Philip, 2002, Manajemen Pemasaran, Jilid 2, Prenhallindo, Jakarta.

[4] Sugiyono, 2007, Staistika untuk Penelitian, ALFABETA CV., Bandung.

[5] Tjiptono, Fandy, 1997, Strategi Pemasaran, Andi, Yogyakarta.

[6] Tjiptono, Fandy, Diana, Anastasia, 2001, Total Quality Managemen, Andi, Yogyakarta.

[7] Ulrich, Karl T., 2001, Perancangan dan Pengembangan Produk, Salemba Teknika, Jakarta. 